\title{
Socio-Economic Contributions of an Indigenous Tree in Urban Areas of Southwest Nigeria
}

\author{
F.D. Babalola ${ }^{\mathrm{a}}$, T.I. Borokini ${ }^{\mathrm{b}}$, A.O. Onefeli ${ }^{\mathrm{c}}$ and M. Muchie ${ }^{\mathrm{d}}$ \\ ${ }^{a}$ Department of Forest Resources and Management, University of Ilorin, Ilorin, Nigeria; and Centre for Environmental Economics and \\ Policy in Africa, University of Pretoria, South Africa; ${ }^{b}$ National Centre for Genetic Resources and Biotechnology (NACGRAB), P.M.B. \\ 5382, Moor Plantation, Ibadan, Nigeria; ${ }^{c}$ Department of Forest Resources and Management, University of Ibadan, Ibadan, Nigeria; \\ ${ }^{d}$ Institute for Economic Research on Innovation, Tshwane University of Technology, Pretoria, South Africa
}

\begin{abstract}
Indigenous trees have been discovered to be disappearing from urban areas at alarming rates, and the contributions of the existing trees are not adequately documented. Milicia excelsa is an indigenous trees species in tropical Africa and popularly known as Iroko. Due to extensive exploitation for wood production and other socio-economic activities, the tree species is classified as threatened and relics could only be found in a few locations. A survey of the trees in the city of Ibadan was therefore carried out to determine their distribution as well as their socio-economic contributions to the urban people. A semi-structured questionnaire was administered to the people living close to the trees or working in the locations where the trees are sighted to determine the socio-economic benefits. A total of 65 trees $\left(0.14 \mathrm{trees}^{\mathrm{k}} \mathrm{km} \mathrm{k}^{2}\right)$ of $M$. excelsa were sighted. As observed in the city, the benefits of the tree species were categorized as: environmental, medicinal, economic, spiritual and ecological services. Provision of shade that creates a 'microclimatic environment' in the form of cooling effects from the heat of the day was mentioned by about $95 \%$ of the respondents as the major benefit obtained from the trees. A strategy for the conservation of the trees as urban trees and their protection against damage to life and property are considered imperative. There is also a need for an appropriate policy that protects indiscriminate felling of indigenous trees in the city and constant monitoring of the trees' status for any sign of weakness.
\end{abstract}

Keywords: Urban forestry; Milicia excelsa; Iroko; Ibadan; Indigenous tree; Tree benefits

\section{Introduction}

Human use and transformation of land since the time of the Industrial Revolution has been unprecedented and has resulted in the loss of biological diversities and alterations to the functioning of the ecosystem (Turner et al., 1994; Vitousek, et al., 1997). Urbanization has been one of the major factors leading to land-use change. According to the United Nations (2004), most of the population growth in the next few decades will occur by expansion of existing urban areas. Nigeria, for instance, has been regarded as the most populous nation in Africa with a teaming population of over 160 million crowded over a land area of about $923,000 \mathrm{~km}^{2}$. The country has over 100 cities with most of the population dwelling in urban centres. Some of the cities with high population densities in Nigeria include Lagos, Kano and Ibadan (Wikipedia, 2013). One of the consequences of a concentration of the population in such cities is that there will be more pressure on land and high urban dynamics (Oluseyi, 2006).

Ibadan is an ancient city with the name originating from Eba Odan, meaning a settlement beside the savannah. Historians say that Ibadan was established in the forest region with many hills and close to the savannah region. The fact that Ibadan was established in a forest region once occupied by trees is evidenced in the names of some of the streets and areas within the city given after the trees that formerly or still stand in those areas. These include Idi-Ose (Ose is the local name for Adansonia digitata), Idi-Ayunre (Ayunre is the local name for Albizia odoratissima), IdiOro (Oro is the local name for Irvingia gabonensis), IdiOsan (Osan is the local name for oranges, Citrus spp), Idi-mangoro (mangoro is the local name for mango, Mangifera indica), Idi-Ishin (Ishin is the local name for Blighia sapida), among many others. In most of these places, however, the trees from which the area got its name have been felled (Borokini, 2011). The same trend is also obtainable in other South-western cities, such as Idi-Araba in Lagos (Araba is the local name for Ceiba petandra), IdiIroko in Abeokuta, Ogun state (Iroko is the local name for Milicia excelsa) (Borokini, 2011). However, with the increasing influx of migrants into Ibadan and an improved economy, the city is expanding with more wild areas being opened up and buildings being erected, mostly for residential purposes. However, despite the fact that there is rapid expansion in all corners of the city, many of the trees are

\footnotetext{
*Corresponding author. Email: folababs2000@yahoo.com 
maintained in their locations, some are felled and many new ones are planted for various purposes, by individuals or the Government. In a study conducted by Borokini (2011), over 62 tree species were observed in the city, notable of which is M. excelsa.

Milicia excelsa is a large deciduous fast-growing forest trees species, native to tropical Africa, most especially West and East Africa. The distribution of M. excelsa ranges from Senegal and Gambia in West Africa, through Central and East Africa to Mozambique (Keay, 1989). M. excelsa occurs in deciduous, semi-deciduous or evergreen, primary or secondary forest, with an apparent preference for drier forest types. The mature tree of M. Excelsa has a relatively large crown with many leaves. The tree often occurs in gallery forest and in forest islands or as lone trees in savanna regions, and is sometimes left as a lone tree in old cultivated areas (Ofori, 2007). Milicia excelsa is classified as 'lower risk but near threatened' in the International Union for Conservation of Nature (IUCN) Red list of threatened species (WCMC, 1998), the main threats being habitat loss and degradation due to expanding agriculture, overexploitation of the wood, and Phytolyma fusca attacks. Known as the Iroko tree, it produces one of the world's most valuable commercial timbers; the timber is strong, moderately hard, and very durable with interlocked and sometimes irregular grain (Ofori, 2007). The timber is used for construction work, ship building and marine carpentry, sleepers, sluice gates, framework, trucks, draining boards, outdoor and indoor joinery, stairs, doors, frames, garden furniture, cabinet work, panelling, flooring and profile boards for decorative and structural uses (Ofori, 2007). It is also used for carving, domestic utensils, musical instruments and toys. As it is resistant to acids and bases, it is used for tanks and barrels for food and chemical products and for laboratory benches. It is used as sliced veneer but only rarely as rotary veneer. The wood is also used as firewood and for making charcoal (Ofori, 2007).

The importance of having trees in human settlements has been emphasized. This has created more awareness and generated interest among urban foresters. Urban forest simply refers to trees and forests located in cities, including ornamental and grown trees, street and parkland trees, protected forests and green areas (Kuchelmeister, 2000). Miller (1997) defined urban and peri-urban forestry (UPF) as "an integrated, citywide approach to the planting, care, and management of trees in the city to secure multiple environmental and social benefits for urban dwellers." Grey and Deneke (1986) provided a more elaborate definition of UPF as the planned, integrated, and systematic approach to the management of trees in urban and peri-urban areas for their contribution to the physiological, sociological, and economic well-being of urban society. Trees planted along the avenues of African capital cities, contribute to the plant diversity (IUCN, 1994). The indirect benefits of an urban landscape covered with trees for physical and mental health has been documented in industrialized countries (Ulrich, 1984). It is demonstrated that plants have the capacity to absorb contaminants from the cities, thus they are called "the lungs of cities" (McPherson et al., 2005; Yang et al., 2005). They represent places of pastime, leisure, recreation and decoration that are necessary for human life. They contribute to the improvement of air quality, thus having a positive impact on health, with effects as obvious as the decrease in cases of respiratory diseases (McPherson et al., 2005). Despite advanced study elsewhere, there is very little literature that addresses the presence of trees in urban areas in subSaharan Africa (SSA).

Nigeria has been experiencing increased urbanization over the last five decades. The proportion of the population living in urban centres has risen from $15 \%$ in 1960 to $43.3 \%$ in 2000 . The total area taken up by urbanization in Nigeria during the same period increased by $131 \%$ from $2,083 \mathrm{~km}^{2}$ in 1976 to $5,444 \mathrm{~km}^{2}$ in 2000 , with an average rate of urbanization estimated to be $3.7 \%$ per year (National Population Commission, 2004). The number of urban centres (settlements with populations of 20,000 or more) increased from 56 in 1953 to 359 in 1991 and to 450 in 2000. Cities occupy less than 3\% of the global terrestrial surface, but account for $78 \%$ of carbon emissions, $60 \%$ of residential water use and $76 \%$ of wood used for industrial purposes (Grimm et al., 2008). With urbanization comes population explosion and its attendant adverse environmental consequences. Therefore, urban forestry offers a solution to some of the environmental challenges in the cities.

As a result of the population explosion, pressure on the remaining forest resources - especially the indigenous tree species - in the city is also on the increase. It has been discovered that about $44 \%$ of the population currently lives in urban areas of developing countries (UN-Habitat, 2009; Montgomery, 2008), and it was estimated that by 2030 , $60 \%$ of all people are expected to reside in cities and towns (Töpfer, 2001). Melicia excelsa is among the few remaining indigenous tree species under great threat in Ibadan city and its metropolis. A larger percentage of the remaining few tree species currently exists in places which are not easily accessible, and places with considerable levels of protection and restriction from felling. The study is therefore a survey of the remaining Melicia stands in Ibadan metropolis with the view to determining their distribution and current status as well as the socio-economic significance to the people living close to the stands.

\section{Methodology \\ Study area}

The study is conducted in Ibadan, the capital of Oyo State and located in South-west Nigeria. The city of Ibadan is located approximately on longitude $3^{\circ} 5^{\prime}$ East of the 
Greenwich Meridian and latitude $7^{\circ} 23^{\prime}$ North of the Equator. Ibadan is a large sprawling city with no discernible pattern of growth or development and this has earned the city such epithets as "the world's largest indigenous city," "the black metropolis" or "the largest urban village in Africa" (Oluseyi, 2006). It is about $145 \mathrm{~km}$ north-east of Lagos, the federal capital of Nigeria. Its population is 2,550,593 according to the 2006 census results, including 11 local government areas (National Bureau of Statistics, 2007). Since its foundation in the 1800 s, the city has had rapid growth; in fact it was regarded as one of the pre-colonial urban centres of Nigeria (Mabogunje, 1968). The developed land increased from only 100 ha in 1830 to 12 $\mathrm{km}^{2}$ in $1931,30 \mathrm{~km}^{2}$ in $1963,112 \mathrm{~km}^{2}$ in $1973,136 \mathrm{~km}^{2}$ in 1981 and $214 \mathrm{~km}^{2}$ in 1988 . Similarly, in 1856 , the population was estimated at 60,000 ; by 1890 , it had increased to about 200,000; in 1963, it was 600,000, and it was almost 2 million in 1987 (NISER, 1988).

With a land area of $128 \mathrm{~km}^{2}$, the overall population density of Ibadan metropolitan area is 586 persons per $\mathrm{km}^{2}$. Ibadan people belong to the Yoruba tribe, with a relatively high migrant population from other parts of Nigeria. Economic activities undertaken by people in Ibadan include trading, public service employment and agriculture in decreasing order of importance. Ibadan metropolitan area covers a total land area of $3,123 \mathrm{~km}^{2}$ of which the main city covers $463.33 \mathrm{~km}^{2}$. This includes the banks of streams as well as the isolated wetland areas that dot the city, which is enclosed by valleys and swamps. Eleven local government areas are grouped together in what is called the Ibadan metropolitan area, Ibadan region or Ibadan land. The administrative and commercial importance of Ibadan has resulted in land being a key investment asset and a status symbol for the population. Economic activities undertaken by people in Ibadan include trading, public service employment and agriculture.

The city ranges in elevation from $150 \mathrm{~m}$ in the valley area, to $275 \mathrm{~m}$ above sea level on the major north-south ridge which crosses the central part of the city. Ibadan has a tropical wet and dry climate with a lengthy wet season and relatively constant temperatures throughout the course of the year. Ibadan's wet season runs from March through October. November to February forms the city's dry season, during which Ibadan experiences the typical West African harmattan (Wikipedia, 2012).

\section{Data collection}

Trees of different species are scattered all over the city of Ibadan (Figure 1); with more exotic species than indigenous species. The map of the city of Ibadan was obtained and subsequently divided into sections. A reconnaissance survey was conducted at the preliminary stage of the study to confirm the existence of Iroko trees within each of the sections marked on the map. Direct observation of the already identified Iroko trees was then carried out during the actual data collection stage of the study.

The Iroko tree is one of the trees with high esteem in society due to its socio-cultural potentials. People are always prevented from carrying out unsolicited activities on the tree or near it. Once a tree was located from a distance, permission was sought to access it and, if possible, to conduct enumeration. If permission was granted, necessary data like coordinates and altitude, and anthropogenic activities were collected, while observations on anthropogenic activities on the tree or around it were carried out. Trees that could not be accessed or where permission was not granted were noted for their locations. A questionnaire was designed and administered to people living close to any of the identified tree species. Questions contained in the questionnaire were designed to obtain information on the benefits of the trees to the people.

\section{Results}

A vast number of Iroko trees in the city of Ibadan have been removed mainly for timber and wood purposes; this leaves scattered trees still coping to survive. A larger percentage of the sighted tree species exists in academic and research institutes with considerable levels of protection against tree felling (Figure 2(a)). The Iroko trees were also found along some of the major streets in the city and protected by those that own them. A total of 65 stands of M. excelsa were sighted during the survey within Ibadan metropolis. With a total land area of $463.33 \mathrm{~km}^{2}$ for Ibadan city, this gives 0.14 trees $/ \mathrm{km}^{2}$. Out of the total observed trees, $33(53.2 \%)$ were accessed and enumerated (Table 1) while the remaining $32(46.8 \%)$ were inaccessible due to perimeter fences restricting entrance into the compound where the trees were located and marshy conditions surrounding the trees (Table 2).

\section{Socio-economic characteristics of the respondents}

One hundred and fifty respondents were sampled for information on the socio-economic contributions of the trees. As presented in Table 3, about $66.7 \%$ of the respondents were male with about $33.3 \%$ in the age class of $31-40$ years, followed by those in the $41-50$ years $(26.7 \%)$ age class. Furthermore, $33.3 \%$ of the respondents attended secondary school as their highest level of education followed by $23.3 \%$ who attended primary education and $20.0 \%$ who had diplomas while $13.3 \%$ attended university education and $10.0 \%$ had no formal education. The major tribe in the city was Yoruba.

About $93.3 \%$ of the sampled respondents found close to the trees were there to carry out trading activities; this means that the trees are important for economic activities going on in the city. Ranked top of the economic activities that the 


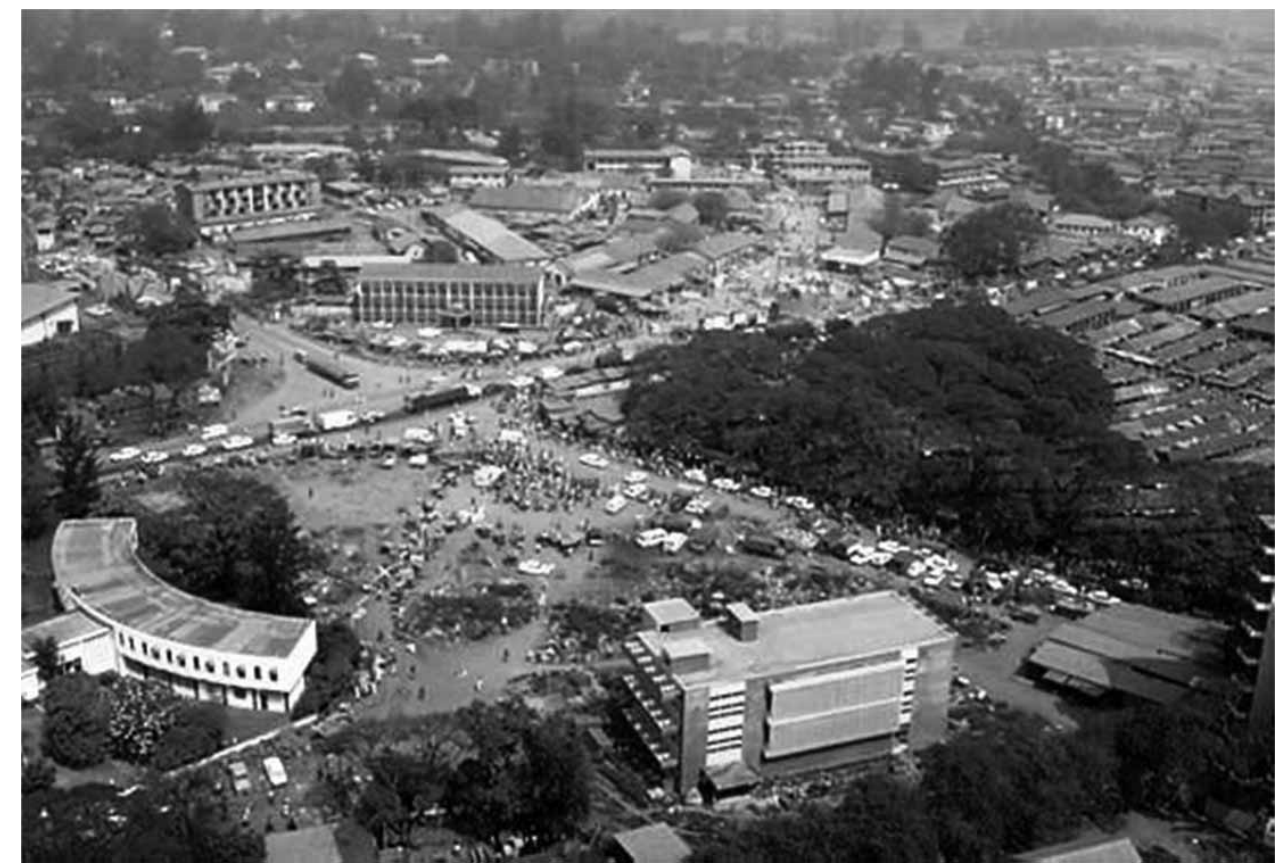

Figure 1. Cross section of Ibadan City with scattered trees of different species

respondents sampled around the trees were involved in were automobile mechanics (34.7\%); this was followed by carpenters $(23.3 \%)$ and food sellers $(20.0 \%)$. This shows that the majority of the people working close or under the trees were artisans and self-employed (Table 3).

\section{Knowledge and perception of Melicia excelsa}

Information obtained from the respondents revealed that $76 \%$ knew the local name of the tree and gave it as either Iroko or Oluwere. In addition, none of the respondents knew who planted the trees, although $56 \%$ believed that (a)

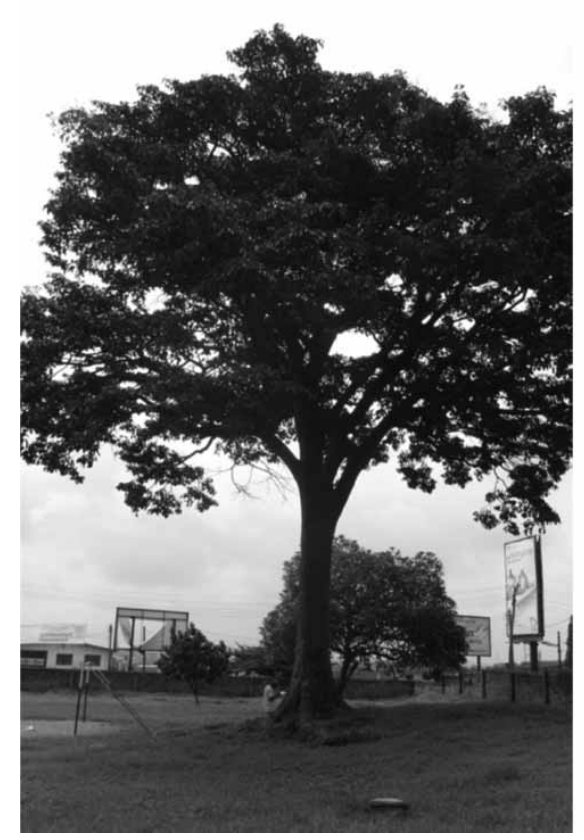

(b)

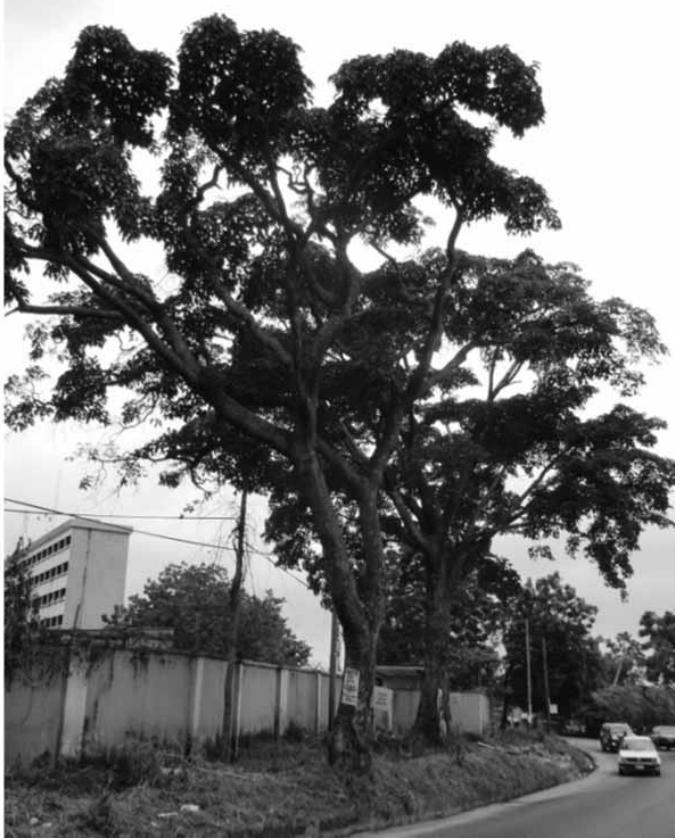

Figure 2. (a) An Iroko tree in an academic institution and (b) on the street in Ibadan, Oyo State, Nigeria Source: Field survey, 2011. 
Table 1. Accessed and enumerated Iroko trees (Milicia excelsa) in Ibadan, Oyo State, Nigeria

\begin{tabular}{|c|c|c|c|}
\hline $\mathrm{S} / \mathrm{N}$ & Location & Coordinate/altitude & Physical observations and utilizations \\
\hline 1 & All Souls' Church, Bodija & $\begin{array}{l}\mathrm{N} 07^{\circ} 25.161^{\prime} \\
\quad \mathrm{E} 003^{\circ} 54.087^{\prime} \\
\quad 214 \mathrm{~m}\end{array}$ & $\begin{array}{l}\text { Big tree, solitary, with many dried branches, forked. Bark slashing. } \\
\text { Colony of birds converged on the tree. }\end{array}$ \\
\hline 2 & Custom-Federal Sec. Road (1) & $\begin{array}{l}\mathrm{N} 07^{\circ} 24.771^{\prime} \\
\quad \mathrm{E} 003^{\circ} 54.823^{\prime} \\
\quad 204 \mathrm{~m}\end{array}$ & $\begin{array}{l}\text { Dry branches at the crown, debarking and bark slashing observed. } \\
\text { Orchids growing on the tree, bole forked above DBH. Excessive branching. }\end{array}$ \\
\hline 3 & Custom-Federal Sec. Road (2) & $\begin{array}{l}\mathrm{N} 07^{\circ} 24.773^{\prime} \\
\quad \mathrm{E} 003^{\circ} 54.810^{\prime} \\
225 \mathrm{~m}\end{array}$ & $\begin{array}{l}\text { Bark slashing observed, branching. } \\
\text { Fetish materials nailed to the tree. }\end{array}$ \\
\hline 4 & NACGRAB (1) & $\begin{array}{l}\mathrm{N} 07^{\circ} 23.315^{\prime} \\
\quad \mathrm{E} 003^{\circ} 50.465^{\prime} \\
165 \mathrm{~m}\end{array}$ & Fairly straight bole. Orchids observed on the branches. \\
\hline 5 & NACGRAB (2) & $\begin{array}{l}\mathrm{N} 07^{\circ} 23.273^{\prime} \\
\quad \mathrm{E} 003^{\circ} 50.341^{\prime} \\
166 \mathrm{~m}\end{array}$ & Relatively young tree. Bark slashing observed. \\
\hline 6 & NACGRAB (3) & $\begin{array}{l}\mathrm{N} 07^{\circ} 23.211^{\prime} \\
\quad \mathrm{E} 003^{\circ} 50.323^{\prime} \\
184 \mathrm{~m}\end{array}$ & No physical defect \\
\hline 7 & Forestry college - Idi Isin Road & $\begin{array}{l}\mathrm{N} 07^{\circ} 23.884^{\prime} \\
\text { E } 003^{\circ} 51.767^{\prime} \\
206 \mathrm{~m}\end{array}$ & No physical defect \\
\hline 8 & Forestry College of Forestry, Jericho & $\begin{array}{l}\mathrm{N} 07^{\circ} 23.876^{\prime} \\
\text { E } 003^{\circ} 51.780^{\prime} \\
206 \mathrm{~m}\end{array}$ & No physical defect \\
\hline 9 & Church Street, Sanngo & $\begin{array}{l}\mathrm{N} 07^{\circ} 25.856^{\prime} \\
\text { E } 003^{\circ} 53.704^{\prime} \\
220 \mathrm{~m}\end{array}$ & $\begin{array}{l}\text { Main tree is felled, but another tree developed from } \\
\text { coppice with excessive and crooked crown. } \\
\text { Fetish materials found on the bole }\end{array}$ \\
\hline 10 & Maryhill Convent School, Agodi & $\begin{array}{l}\mathrm{N} 07^{\circ} 24.215^{\prime} \\
\text { E } 003^{\circ} 55.527^{\prime} \\
252 \mathrm{~m}\end{array}$ & $\begin{array}{l}\text { Straight bole with good crown shape. } \\
\text { Orchids growing on the branches. }\end{array}$ \\
\hline 11 & MFM, UMC, Molete & $\begin{array}{l}\mathrm{N} 07^{\circ} 21.784^{\prime} \\
\text { E } 003^{\circ} 53.233^{\prime} \\
188 \mathrm{~m}\end{array}$ & No physical defect \\
\hline 12 & After Ikolaba Pry School & $\begin{array}{l}\mathrm{N} 07^{\circ} 24.487^{\prime} \\
\text { E } 003^{\circ} 55.102^{\prime} \\
217 \mathrm{~m}\end{array}$ & $\begin{array}{l}\text { Straight bole, forked above } 9 \mathrm{~m} \\
\text { Bark slashing observed. Brown exudates at the DB. }\end{array}$ \\
\hline 13 & $\mathrm{UCH}(1)$ & $\begin{array}{l}\mathrm{N} 07^{\circ} 24.069^{\prime} \\
\text { E } 003^{\circ} 54.554^{\prime} \\
221 \mathrm{~m}\end{array}$ & Large buttress, old tree. \\
\hline 14 & UCH (2) & $\begin{array}{l}\mathrm{N} 07^{\circ} 24.101^{\prime} \\
\text { E } 003^{\circ} 54.583^{\prime} \\
206 \mathrm{~m}\end{array}$ & Excessive branching, orchids growing on it. \\
\hline 15 & UCH (3) & $\begin{array}{l}\mathrm{N} 07^{\circ} 24.131^{\prime} \\
\text { E } 003^{\circ} 53.952^{\prime} \\
188 \mathrm{~m}\end{array}$ & Excessive branching, orchids growing on it. \\
\hline 16 & UCH (4) & $\begin{array}{l}\mathrm{N} 07^{\circ} 24.138^{\prime} \\
\text { E } 003^{\circ} 33.951^{\prime} \\
200 \mathrm{~m}\end{array}$ & $\begin{array}{l}\text { No defect on the bole. } \\
\text { Colony of scavenger birds lives on it. }\end{array}$ \\
\hline 17 & UCH (5) & $\begin{array}{l}\mathrm{N} 07^{\circ} 24.215^{\prime} \\
\quad \mathrm{E} 003^{\circ} 53.981^{\prime} \\
210 \mathrm{~m}\end{array}$ & $\begin{array}{l}\text { Forked, hollow and root rot observed at the base. } \\
\text { Debarking observed. }\end{array}$ \\
\hline
\end{tabular}




\begin{tabular}{|c|c|c|c|}
\hline $\mathrm{S} / \mathrm{N}$ & Location & Coordinate/altitude & Physical observations and utilizations \\
\hline 18 & UCH (6) & $\begin{array}{l}\mathrm{N} 07^{\circ} 24.219^{\prime} \\
\quad \mathrm{E} 003^{\circ} 54.177^{\prime} \\
\quad 208 \mathrm{~m}\end{array}$ & \\
\hline 19 & UCH (7) & $\begin{array}{l}\mathrm{N} 07^{\circ} 24.254^{\prime} \\
\quad \mathrm{E} 003^{\circ} 54.340^{\prime} \\
214 \mathrm{~m}\end{array}$ & Human disturbance (burning) observed around it. \\
\hline 20 & $\mathrm{UCH}(8)$ & $\begin{array}{l}\mathrm{N} 07^{\circ} 24.185^{\prime} \\
\quad \mathrm{E} 003^{\circ} 54.413^{\prime} \\
\quad 208 \mathrm{~m}\end{array}$ & Epiphytes growing on it, posters nailed on the bole. \\
\hline 21 & UCH (9) & $\begin{array}{l}\mathrm{N} 07^{\circ} 24.135^{\prime} \\
\quad \mathrm{E} 003^{\circ} 54.533^{\prime} \\
214 \mathrm{~m}\end{array}$ & Fairly straight bole \\
\hline 22 & Segelu bus stop, Iwo Road & $\begin{array}{l}\mathrm{N} 07^{\circ} 24.034^{\prime} \\
\quad \mathrm{E} 003^{\circ} 56.923^{\prime} \\
222 \mathrm{~m}\end{array}$ & Few debarking observed, named 'igi anu'. \\
\hline 23 & Adegbayi, Olode, New Ife Road (1) & $\begin{array}{l}\mathrm{N} 07^{\circ} 22.954^{\prime} \\
\quad \mathrm{E} 004^{\circ} 00.368^{\prime} \\
162 \mathrm{~m}\end{array}$ & $\begin{array}{l}\text { Fairly straight bole, debarking observed, base infected by termites, } \\
\text { a seedling observed close by infected by Phytolyma fusca }\end{array}$ \\
\hline 24 & Adegbayi, Olode, New Ife Road (2) & $\begin{array}{l}\mathrm{N} 07^{\circ} 22.950^{\prime} \\
\quad \mathrm{E} 004^{\circ} 00.362^{\prime} \\
\quad 159 \mathrm{~m}\end{array}$ & $\begin{array}{l}\text { Straight bole. } \\
\text { Debarking observed. }\end{array}$ \\
\hline 25 & Old Ife Road, beside Green Spring hotel & $\begin{array}{l}\mathrm{N} 07^{\circ} 23.443^{\prime} \\
\text { E } 003^{\circ} 56.004^{\prime} \\
223 \mathrm{~m}\end{array}$ & $\begin{array}{l}\text { Debarking observed, termite infection at the base, straight bole. A lunatic } \\
\text { used to live in the hollow at the base. } \\
\text { Sacrifices and fetish substances observed at the base. }\end{array}$ \\
\hline 26 & Government House, Agodi 1 \& 2 & $\begin{array}{l}\mathrm{N} 07^{\circ} 24.567^{\prime} \\
\text { E } 003^{\circ} 55.028^{\prime} \\
258 \mathrm{~m}\end{array}$ & $\begin{array}{l}\text { Forking at the base, so considered as two stands. } \\
\text { Colony of birds observed on the crown. }\end{array}$ \\
\hline 27 & Awolowo Road, Old Bodija & $\begin{array}{l}\mathrm{N} 07^{\circ} 24.969^{\prime} \\
\text { E } 003^{\circ} 54.264^{\prime} \\
224 \mathrm{~m}\end{array}$ & Bole is crooked, no bark slashing observed. \\
\hline 28 & IAR\&T, Moor Plantation & $\begin{array}{l}\mathrm{N} 07^{\circ} 22.471^{\prime} \\
\quad \mathrm{E} 003^{\circ} 50.771^{\prime} \\
165 \mathrm{~m}\end{array}$ & Forked, debarking observed. \\
\hline 29 & Behind Mobil filling station, Iwo Road & $\begin{array}{l}\mathrm{N} 07^{\circ} 23.917^{\prime} \\
\text { E } 003^{\circ} 56.891^{\prime} \\
246 \mathrm{~m}\end{array}$ & $\begin{array}{l}\text { Dry crown/branches, straight bole. } \\
\text { Deep/intensive debarking observed. }\end{array}$ \\
\hline 30 & Adegbayi, opposite Honors Filling station & $\begin{array}{l}\mathrm{N} 07^{\circ} 23.191^{\prime} \\
\quad \mathrm{E} 003^{\circ} 59.030^{\prime} \\
\quad 220 \mathrm{~m}\end{array}$ & A young developing tree with rapid growth. \\
\hline 31 & NIHORT, Jericho & $\begin{array}{l}\mathrm{N} 07^{\circ} 24.468^{\prime} \\
\quad \mathrm{E} 003^{\circ} 50.836^{\prime} \\
173 \mathrm{~m}\end{array}$ & Hollow on the base of the bole \\
\hline 32 & Gbekuba area & $\begin{array}{l}\mathrm{N} 07^{\circ} 23.640^{\prime} \\
\quad \mathrm{E} 003^{\circ} 50.416^{\prime} \\
\quad 159 \mathrm{~m}\end{array}$ & $\begin{array}{l}\text { Deliberate ring barking of the tree to fell the young tree, possibly to allow } \\
\text { for construction activities. Other trees around were also ring barked }\end{array}$ \\
\hline
\end{tabular}

Note: NACGRAB - National Centre for Genetic Resources and Biotechnology. UCH - University College Hospital. IAR \& T - Institute of Agricultural Research and Training. MFM - Mountain of Fire an Miracle Ministry.

Source: Field survey, 2011 
Table 2. Iroko trees that were not accessed and studied

\begin{tabular}{|c|c|c|c|}
\hline $\mathrm{S} / \mathrm{N}$ & Locations & Quantity & Reason for inaccessibility \\
\hline 1 & Inside Nigerian Breweries, New Ife Road & 5 & Restricted \\
\hline 2 & Yidi Islamic Praying ground, Agodi & 2 & Restricted \\
\hline 3 & Agodi Gardens & 3 & Commercialized \\
\hline 4 & Oyo State Secretariat area & 1 & Impenetrable \\
\hline 5 & Church street, Sanngo & 1 & Fenced \\
\hline 6 & NIHORT, Jericho & 1 & Impenetrable \\
\hline 7 & Ikolaba GRA & 1 & Impenetrable \\
\hline 8 & Maryhill Convent School & 1 & Restricted \\
\hline 9 & Apata - Omi Adio & 1 & Oversight \\
\hline 10 & Onireke & 3 & Restricted \\
\hline 11 & Immanuel College, Samonda & 3 & Restricted \\
\hline 12 & Moor Plantation & 1 & Impenetrable \\
\hline 13 & Joyce B’ Road & 2 & Restricted \\
\hline 14 & High Court/Oni \& Sons, Ring Road & 1 & Restricted \\
\hline 15 & Ibadan Golf Club & 2 & Restricted \\
\hline 16 & Osuntokun Avenue, Old Bodija & 1 & Oversight \\
\hline \multirow[t]{2}{*}{17} & Onireke Road & 3 & Oversight \\
\hline & Total & 32 & \\
\hline
\end{tabular}

Source: Field survey, 2011

Table 3. Demographic characteristics of the people living and working around Melicia excelsa stands in Ibadan, Nigeria

\begin{tabular}{|c|c|c|c|}
\hline $\mathrm{S} / \mathrm{N}$ & Demographic information & Frequency $(\mathrm{n}=150)$ & Percentage \\
\hline \multirow[t]{4}{*}{1} & Gender & & \\
\hline & - Male & 100 & 66.7 \\
\hline & - Female & 50 & 33.3 \\
\hline & Sub total & 150 & 100 \\
\hline \multirow[t]{8}{*}{2} & Age category (years) & & \\
\hline & - Below 20 & 10 & 6.7 \\
\hline & $-\quad 21-30$ & 25 & 16.7 \\
\hline & $-\quad 31-40$ & 50 & 33.3 \\
\hline & $-41-50$ & 40 & 26.7 \\
\hline & $-51-60$ & 15 & 10.0 \\
\hline & - Above 60 & 10 & 6.7 \\
\hline & Sub total & 150 & 100 \\
\hline \multirow[t]{7}{*}{3} & Highest level of education & & \\
\hline & - No formal & 15 & 10.0 \\
\hline & - Primary & 35 & 23.3 \\
\hline & - Secondary & 50 & 33.3 \\
\hline & - Diploma & 30 & 20.0 \\
\hline & - Degree & 20 & 13.3 \\
\hline & Sub total & 150 & 100 \\
\hline \multirow[t]{4}{*}{4} & Do you work/reside close to the M. excelsa stand & & \\
\hline & - Work & 140 & 93.3 \\
\hline & - Reside & 10 & 6.7 \\
\hline & Sub total & 150 & 100 \\
\hline \multirow[t]{9}{*}{5} & Main occupation & & \\
\hline & - Automobile mechanic & 52 & 34.7 \\
\hline & - House caretaker & 10 & 6.7 \\
\hline & - Food seller & 30 & 20 \\
\hline & - Carpenter & 35 & 23.3 \\
\hline & - Clergy & 8 & 5.3 \\
\hline & - Police station staff & 2 & 1.3 \\
\hline & - Hairdresser & 13 & 8.7 \\
\hline & Sub total & 150 & 100 \\
\hline
\end{tabular}

Source: Field survey, 2011 
(a)

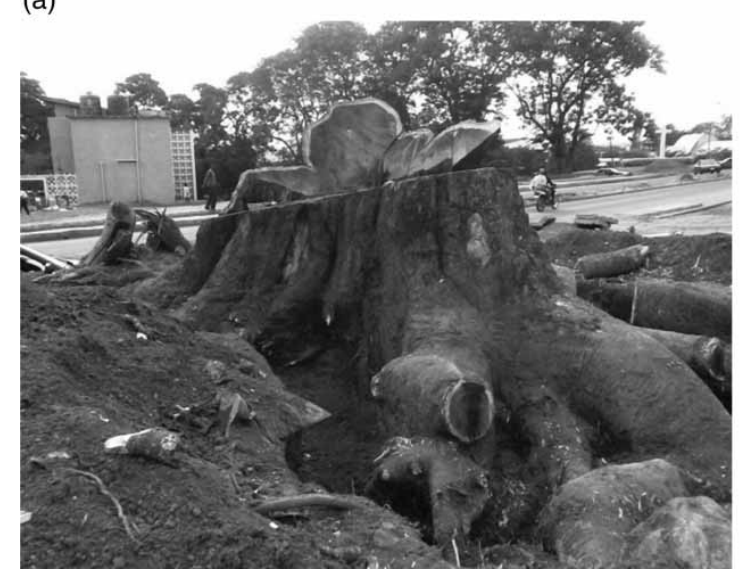

(b)

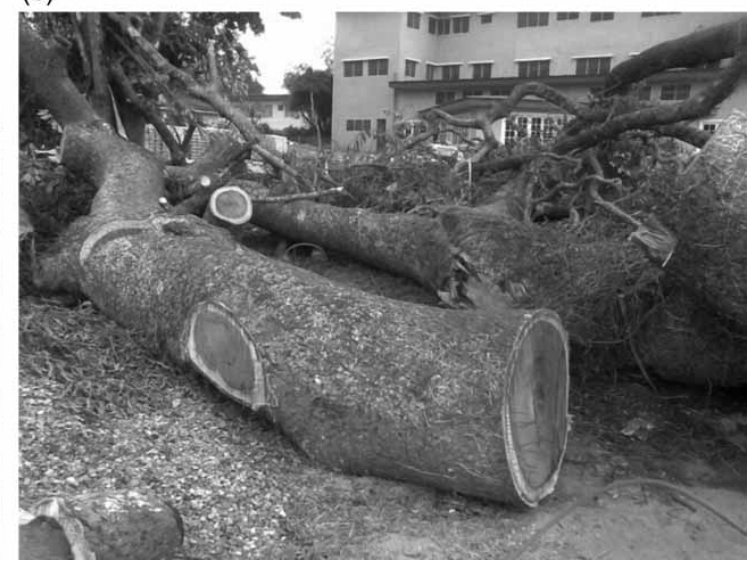

Figure 3. An Iroko tree felled in Ibadan to give way for construction process

the landowner automatically owned the tree; this was corroborated by a land tenant, who happened to be among the respondents, that he is the owner of the tree since he planted it and it is on his land. Furthermore, the majority $(68 \%)$ of the respondents did not know the age of the tree, while the rest gave estimates of the age of the trees close to them ranging from over 20 to 50 years old.

About $56 \%$ of the respondents did not support felling of the trees located around them; however $20 \%$ wanted the trees to be removed while $24 \%$ were indifferent. A felled Iroko tree was observed (Figure 3) during the data collection, and the reason for felling the tree was to give way for construction processes. Actually, factors such as construction purposes, demand for the wood, population explosion and urbanization process are some of the major factors that have been leading to felling of most of the indigenous tree species in urban areas. Apart from these factors, the respondents that supported felling of the trees in Ibadan were further asked the reason for the support. The majority of the respondents indicated that the trees pose danger to life and property while others believe that the trees habour some 'evil' spirits. About $20 \%$ of the respondents further informed that the existing trees could not be felled due to the position of the trees; if felled, it would cause serious damage to houses, electricity poles, and other public and private properties in the process.

\section{Benefits of the Iroko trees in the city}

Several uses of this tree species were documented in the course of the study. The utilizations are therefore grouped into 5 categories:

Environmental services: Provision of shade and creation of a 'microclimatic environment' in the form of cooling effects from the heat of the day were mention by about $95 \%$ of the respondents as the major benefit obtained from the trees. This influenced the siting of small-scale workshops and other artisans under the trees, especially the automobile mechanics and food vendors. The trees also serve as a wind break during the rainy season. In addition, some of the Iroko trees were located within the Muslim praying grounds alongside several other trees, indicating their significance to religious activities within the city.

Medicinal: Bark slashing was observed on 23 of the accessed tree stands. About $40 \%$ of the respondents reported that the removed bark was used mainly for medicinal purposes. Herb sellers do visit the standing trees to peel the bark which is used for the preparation of local herbal medicines used for treating various sicknesses and illnesses from malaria to coughs to mental disorders. In addition, the milky sap from the tree trunks and branches is used to treat arthritis, body pains and rheumatism, and dressing of wounds while the boiled leaves, mixed with the leaves of Physalis angulata, are used to treat malaria. This means that the leaves and bark of the tree have high potential for the treatment of malaria which is a prevalent sickness in tropical Africa. There is therefore the need for further research into the active ingredient in the bark and leaves of the tree for use as pharmaceutical materials in modern medicines.

Spiritual: About $80 \%$ of the respondents believed that some 'spirit' called oluwere resides inside the trees and is worshipped by the traditionalists. To support this, fetish objects were seen on the trunk of some of the trees accessed in different locations within the city. Some respondents informed that one 'insane man' lived in the hollow formed at the base of one of the trees a few months ago, and they attributed this to the spirit living in the tree.

Economic: The sampled food vendors stated that they use the fallen dried branches of the standing trees as fuel wood. In addition, posters and bills were found nailed to the trunk of the tree stands located by roadsides thereby serving as an advertisement medium. The collection and sale of tree bark by herb sellers as well as various trading activities carried out around and under the trees are some of the economic benefits of the trees in the city. 
Ecological: Some of the Iroko trees act as phorophytes for orchids and other epiphytes, which live on their branches and crowns. Furthermore, several birds were found living on some of the trees. Different kinds of bird nests were observed on the tree crowns, most especially those of large and scavenger birds, such as pied crows, were seen on the tree branches. These trees therefore support breeding as well as natural roosting places for the birds within the city.

All these benefits of Iroko trees signify the valuable contributions of the remaining trees within the city of Ibadan. The trees provide both tangible and intangible benefits to the people of Ibadan, especially those who carry out various trading activities under and close to them. In one of the locations, the tree was named igi anu (tree of mercy) by the people because of the immeasurable benefits they derive from the tree.

\section{Adverse effects of the standing tree}

When asked for some of the adverse effects of the trees, 28\% of the respondents replied that the trees had some direct or indirect adverse effects. Some of the identified adverse effects of the trees include damages cause by fallen dried branches to the roof of buildings and windscreens of cars parked under the trees. Some people said that birds that live on the trees drop remnants of dead lizards, frogs and other prey onto their roofs and surroundings, thereby causing foul and offensive odours within the environment.

\section{Discussion}

The need for trees in urban settlements has been stressed. This study revealed that $M$. excelsa trees within Ibadan metropolis have been very useful to the people around it. The fact that almost all the respondents knew the name of the tree confirmed that the tree is very popular. The emerging trend in urban forestry is to replace the indigenous trees with exotic species. It is therefore uncommon to see indigenous forest trees around residential buildings. Most trees would have been cleared during land preparation for construction and building purposes. Many of the remaining indigenous trees therefore exist on land yet to be used for building or construction, or places that do not permit indiscriminate felling of trees.

Scientific discoveries about the tree species have cleared some misconceptions and beliefs about the propagation of Iroko. For instance, the local people believe that no one can plant the tree unless it sprouts by itself. Meanwhile, studies have revealed that the seeds of the tree species are very tiny, making them difficult to handle for propagation. It was also discovered that the seeds are mainly dispersed by fruit bats (a nocturnal animal and very active at night), thereby making the mode of dispersal unknown to many people. In the areas where the trees were not planted but established themselves, the owner(s) of the land on which the tree is growing claim its ownership. The people directly benefiting from the trees in most cases nurture and ensure their survival.

All birds need to find a safe place to lay their eggs and rear their young: somewhere protected from extremes of heat or cold and as safe as possible from predators (Nason, 1992). The crowns of tall trees are preferred by most birds of prey, such as the Pied Crow (Corvus albus) among others, found in the city to build their nests for roosting and breeding. It is unfortunate that the indigenous tree species that support this natural requirement by birds are fast disappearing. The remaining Iroko trees in Ibadan city provide this requirement for bird of prey, and they are found in large numbers converging on the tree crowns. The useful purposes of the birds of prey in the urban setting cannot be underestimated. They help in cleaning up the carcasses of dead animals, remove some rats and snakes, and human rubbish, thus preventing the spread of diseases (Nason, 1992). In addition, some of the Iroko trees serve to conserve the plant diversity in the city. For instance, the trees act as phorophytes, thus adding to the existing knowledge on the orchid-phorophyte relationship among orchid species in Nigeria.

The use of fallen dried branches of the tree as fuelwood also signifies the contribution of the Iroko tree to meeting the domestic energy need of some households. It has been reported that wood fuel contributes between 25 and $90 \%$ of household energy supplies in urban areas, especially in smaller urban centres in developing countries (Kuchelmeister, 1998).

Much has been reported on the medicinal uses of Iroko trees in African traditional medicine. According to Ofori (2007), root decoction is taken to treat female sterility, and a decoction of the root and stem bark is taken as an aphrodisiac. Preparations from the bark are taken to treat coughs, asthma, heart trouble, lumbago, spleen pain, stomach pain, abdominal pain, oedema, ascites, dysmenorrhoea, gonorrhoea, general fatigue, rheumatism, sprains, and as a galactagogue, aphrodisiac, tonic and purgative. In addition, preparations from the bark are externally applied to treat scabies, wounds, loss of hair, fever, venereal diseases and sprains; and are also applied as an enema to cure piles, diarrhoea and dysentery. The latex from the stem is applied to burns, wounds, sores and against eczema and other skin problems; also taken against stomach problems, hypertension and as a galactagogue; and used for the treatment of tumours and obstructions of the throat. Leaves are eaten to treat insanity; leaf maceration is drunk as a galactagogue; decoction of the leaves is taken for treatment of gallstones; and leaf preparations are externally applied to treat snakebites and fever and as eye drops to treat filariasis (Ofori, 2007).

Previous studies have revealed the significance of urban trees for human livelihood. Trees and other vegetation 
intercept particles and gaseous pollutants (McPherson et al. 1997; Harris et al. 1999). Moreover, they act as carbon sinks that help mitigate global warming (McPherson \& Simpson, 1999). Trees reduce storm water runoff and can assist with processing wastewater, for example, where other wastewater facilities are insufficient (El Lakany, 1999). Urban trees also protect soils and moderate harsh urban climates by cooling the air, reducing wind speeds, and by shading. In arid regions, forest shelterbelts around cities help combat desertification and dust storms; this has been observed in Burkina Faso and China ( $\mathrm{Lu} \&$ Wang, 2003). Urban woodlands in Europe attract as many as several thousands of visits per hectare per year (Konijnendijk, 1999). Because people tend to prefer outdoor recreational areas close to their homes, urban forest areas are the most popular outdoor recreational areas. Recently, the health impacts of urban forests have also been studied (Grahn \& Stigsdotter, 2003) and their positive impacts on physical and mental health have been discovered, for example, by providing settings for physical exercise, reducing ultraviolet radiation, air pollution and stress. One study has demonstrated that hospital patients placed in rooms with windows facing trees heal faster and require shorter hospital stays (Ulrich, 1990). Improving air quality through the planting of vegetation certainly has an impact on health, with such obvious benefits as decreased incidence of respiratory illnesses.

In West Africa, urban forestry practices that have contributed to improvements in food security include the collection of wild edible plants, planting of fruit bearing street trees and the establishment of multifunctional parks or medicinal public parks. Cars are parked under these trees to protect them from the scorching sun. Humans and domestic animals also take shelter under urban trees because the trees reduce the effect of ultraviolet radiation from the sun. Most schools in urban areas are adorned with trees for students to sit under and relax during break periods. Open markets are planted with trees and traders take advantage of the shade to display their goods and services. In arid regions like Ouagadougou, Yola and Kano, forest shelterbelts around cities help combat desertification and dust storms (Kambou, 1992). In northern Nigeria, Burkina Faso and Gambia, Eucalyptus species interspersed with Acacia, Anacardium and Azadirachta indica provide effective wind breaks (Fuwape, 2005). Trees planted in erosion prone areas in Imo, Anambra, Abia and Enugu states in Nigeria have enhanced water percolation during rainfall and reduced instances of runoff and soil erosion (Fuwape $\&$ Onyekwelu, 2010). Forest covers on steep slopes in different parts of Ghana, Ivory Coast, Benin, Togo and Nigeria were reported to have protected the landscape from the development of gully erosion (Fuwape \& Onyekwelu, 2010).

One of the major problems in urban areas is poor air quality (Kuchelmeister \& Braatz, 1993). Plants help remove pollutants from the air in three ways: absorption by the leaves or the soil surface; deposition of particulates and aerosols on leaf surfaces; and fallout of particulates on the leeward (downwind) side of the vegetation because of the slowing of air movement (Kuchelmeister \& Braatz, 1993). Furthermore, trees absorb sulphur dioxide very efficiently. Keller (1979) has quantified an $85 \%$ reduction in lead behind a shelter-belt of trees, in addition to the report that a belt of trees measuring $30 \mathrm{~m}$ in width has been found to intercept almost all dust in the air. Trees also help to increase the relative humidity of urban air through evapotranspiration. Trees and other vegetation also help to control temperature extremes in urban environments by modifying solar radiation. The shade of one large tree may reduce the temperature of a given building to the same extent as would 15 air conditioners at 4000 British thermal units (BTUs), i.e. $4220 \mathrm{~kJ}$, in a similar but unshaded building. Energy saving through tree-planting around houses ranges from 10 to $50 \%$ for cooling and from 4 to $22 \%$ for heating (NAA/ISA, 1991).

Noise is often referred to as invisible pollution. Excessive noise levels in most major cities contribute to both physical and psychological damage. Trees can help both by absorbing and refracting or dissipating noise such as that produced by the heavy vehicular traffic which characterizes urban areas. Urban trees play a very important social role in easing tensions and improving psychological health; people simply feel better living around trees. Easily accessible trees and woodlands provide a vital facility for both formal and informal learning, as well as for outdoor recreation. All these are indirect, but most important benefits of urban forestry. The Iroko tree also offers similar socioeconomic benefits for the people like other trees, with the exception of being a source of food.

\section{Conclusion}

This study provides information on the social, economic and cultural significances of the remaining Iroko trees in the city of Ibadan. The importance of trees in human life cannot be overemphasized. Apart from the production of oxygen needed for the sustenance of life and protection against some adverse environmental impacts, urban trees also contribute to the economic activities of the people as well as providing roosting and breeding habitats for birds and supporting conservation of biodiversity. With increasing urbanization and expansion of cities all over the world and developing countries specifically, there is an urgent need to give proper attention to urban trees - most especially the indigenous species which are disappearing at alarming rates. A strategy for managing trees in urban settings to prevent damage to life and property is pertinent and should be put in place. A policy to protect indiscriminate felling of trees in the city should be formulated while a management strategy in the form of appropriate and 
constant monitoring of the tree status for any sign of weakness should be developed and properly implemented.

\section{References}

Borokini, T. I. (2011). Diversity, distribution and utilization of urban trees in Ibadan, Southwest Nigeria. Nature and Faune, 26, 54-59

El Lakany, H. (Ed.). (1999). Urban and peri-urban forestry: Case studies in developing countries. Rome: Food and Agriculture Organization, Rome.

Fuwape, J. A. (2005). Forest management for products and services in Nigeria. In Labode Popoola (Ed.), Proceedings of 30th Annual Conference of the Forestry Association of Nigeria. Kaduna, 126-141.

Fuwape, J. A., \& Onyekwelu, J.C. (2011). Urban forest development in West Africa: Benefits and challenges. Journal of Biodiversity and Ecological Sciences, 1, 77-94.

Grahn, P., \& Stigsdotter, U. A. (2003). Landscape planning and stress. Urban Forestry and Urban Greening, 1, 1-18.

Grey, G. W., \& Deneke, F. J. (1986). Urban forestry. New York: Wiley.

Grimm, N. B., Faeth, S. H., Golubiewski, N. E., Redman, C. L., Wu, J., Bai, X., \& Briggs, J. M. (2008). Global change and the ecology of cities. Science, 319, 756-760.

Harris, R. W., Clark, J. R., \& Matheny, N. P. (1999). Arboriculture: integrated management of landscape trees. In Shrubs and Vines, 3rd edn. Englewood Cliffs, NJ: Prentice Hall.

IUCN (1994). Putting plans into action. Report of Metropolitan Open Space Systems (MOSS). International Conference, Durban, Afrique du Sud, 9-11 February.

Kambou, S. (1992). Urban forests in the tropical context: The case of the Forêt Classée du Barrage de Ouagadougou, Burkina Faso. In J. Hummel and M. Parren (Eds), Forests: A growing concern (pp. 48-51). Proceedings of the XIXth International Forestry Students Symposium, Wageningen, The Netherlands, 30 September-7 October 1991.

Keay, R. W. J. (1989). Trees of Nigeria. Oxford: Clarendon Press.

Keller, T. (1979). The possibilities of using plants to alleviate the effects of motor vehicles (TRRL Symposium Report no. 513). DOE/DT.

Konijnendijk, C. C. (1999). Urban forestry in Europe: A comparative study of concepts, policies and planning for forest conservation, management and development in and around major European cities (PhD dissertation). Faculty of Forestry, University of Joensuu.

Kuchelmeister, G. (2000). Trees for the urban millennium: An update on urban forestry. Unasylva, 200, 49-55.

Kuchelmeister, G. (1998). Urban forestry in the Asia-Pacific Region: Status and prospects (APFSOS Working Paper no. 44). Rome: Food and Agriculture Organization.

Kuchelmeister, G., \& Braatz, S. (1993). Urban forestry revisited. Unasylva, 44, 13-18.

Lu, Q., \& Wang, S. (2003). Dust-sand storms in China: Disastrous effects and mitigation strategies. In Forests: Source of life. Congress Proceedings, B - Forests for the Planet. XII World Forestry Congress, Québec City, Québec, 21-28 September 2003.

Mabogunje, A. L. (1968). Urbanization in Nigeria. London: University of London Press.

McPherson, E. G., \& Simpson, J. R. (1999). Carbon dioxide reductions through urban forestry: Guidelines for professional and volunteer tree planters (General Technical
Report no. PSW-171). Albany, CA: USDA Forest Service, Pacific Southwest Research Station.

McPherson, E. G., Nowak, D., Heisler, G., Grimmond, S., Souch, C., Grant, R., \& Rowntree, R. (1997). Quantifying urban forest structure, function, and value: The Chicago urban forest climate project. Urban Ecosystem, 1, 49-61.

McPherson, E. G., Simpson, J. R., Peper, P. J., Maco, S. E., \& Xiao, Q. (2005). Municipal forest benefits and costs in five US cities. Journal of Forestry, 103, 411-416.

Miller, R. W. (1997). Urban forestry: Planning and managing urban greenspaces, 2nd edn. Englewood Cliffs, NJ: Prentice Hall.

Montgomery, M. R. (2008). The urban transformation of the developing world. Science, 319, 761-764.

NAA/ISA (1991). The importance of large tree maintenance in mitigating global climate change. Amherst, MA: National Arborist Association.

Nason, A. (1992). Discovering birds: An introduction to the birds of Nigeria. Newbury: Pisces.

National Bureau of Statistics (2007). 2006 Nigerian Population Census. Available at www.nigerianstat.gov.ng

National Population Commission (2004). National Policy on Population for Sustainable Development 2004, Abuja, Nigeria. National Population Commission.

NISER (1988). Ibadan region. Occasional publication, Nigerian Institute of Social Economic Research Series, 16.

Ofori, D. A. (2007). Milicia excelsa (Welw.) C. C. Berg. Record from Protabase. In D. Louppe, A.A. Oteng-Amoako, \& M. Brink, M, (Eds). Wageningen: PROTA (Plant Resources of Tropical Africa/Ressources végétales de l'Afrique tropicale). Retrieved from http://database.prota.org/search.htm

Oluseyi, O. F. (2006). Urban land use change analysis of a traditional city from remote sensing data: The case of Ibadan metropolitan area, Nigeria. Humanity \& Social Sciences Journal, 1, 42-64.

Töpfer, K. (2001). The crucial importance of urban-rural linkages. In D. Virchow and J. von Braun (Eds), Villages in the future: Crops, jobs and livelihood (pp. 21-24). Berlin: Springer.

Turner II, B. L., Mayer, W. B., \& Skole, D. L. (1994). Global landuse/landcover change towards an integrated study. Ambio, Royal Swedish Academy of Sciences, 23, 91-95.

Ulrich, R. S. (1984). View through a window may influence recovery from surgery. Science, 224, 420-421.

Ulrich, R. S. (1990). The role of trees in wellbeing and health. In P.D. Rodbell (Ed.) Proceedings of the Fourth Urban Forestry Conference, St Louis, MO, 15-19 October.

UN-Habitat (2009). Global report on human settlements 2009 Planning sustainable cities: Policy direction. London: United Nations Human Settlements Programme/Earthscan.

United Nations (2004). World urbanization prospects: the 2003 revision. New York: United Nations, Department of Economic and Social Affairs, Population Division.

Vitousek, P. M., Mooney, H. A., Lubchenco, J., \& Melillo, J. M. (1997). Human domination of Earth's ecosystems. Science, 277, 494-499.

Wikipedia (2012). Ibadan. Retrieved from: http://en.wikipedia. org/wiki/Ibadan

Wikipedia (2013). Nigeria. Retrieved from http://en.wikipedia. org/wiki/Nigeria (Accessed 29 July 2013).

World Conservation Monitoring Centre (WCMC) (1998). Milicia excels. In IUCN 2011. IUCN Red List of Threatened Species. Version 2011.2. Retrieved from www.iucnredlist.org

Yang, J., McBride, J., Zhou, J., \& Sun, J., (2005). The urban forest in Beijing and its role in air pollution reduction. Urban Forestry and Urban Greening, 3, 65. 